\title{
LA OTRA ANTROPOFAGIA. \\ OSWALDO COSTA Y LA CRÍTICA DE LA CUESTIÓN COLONIAL
}

POR

\author{
CArlos A. Jáuregui \\ University of Notre Dame
}

os modernistas [...] Aceitaram uma porção de fórmulas idiotas: que isto é civilização; e aquilo é progresso.

Oswaldo Costa

No hay Modernidad sin 'modernizado'.

Enrique Dussel

Para David M. Solodkow, antropófago

El movimiento brasileño Antropofagia -formado a fines de la década de 1920 alrededor del icónico "Manifesto Antropófago" (1928) de Oswald de Andrade (18901954) y de la Revista de Antropofagia (1928-1929)-ocupa un lugar notable en la historia cultural latinoamericana.

La canonización del movimiento desde finales de los años sesenta y, especialmente, las numerosas lecturas académicas del "Manifesto Antropófago" en las últimas tres décadas, han tendido a reducir Antropofagia a una teoría latinoamericana del consumo cultural avant la lettre, y a ver en ella un discurso que anticiparía nociones como 
transculturación, traducción cultural, ${ }^{1}$ calibanismo, ${ }^{2}$ hibridez y crítica poscolonial. ${ }^{3}$

Antropofagia ciertamente resignificó el caníbal (tropo maestro de la representación etno-cartográfica del Brasil colonial), declaró una ruptura con la tradición literaria decimonónica del indianismo, e intervino en el debate vanguardista sobre la brasilidade versus las influencias culturales europeas. Todo ello, sin definirse conceptualmente. Como anotó certeramente Antônio Cândido en verdad "É difícil dizer no que consiste exatamente aAntropofagia, que Oswald nunca formulou, embora tenha deixado elementos suficientes para vermos embaixo dos aforismos alguns princípios virtuais, que a integram numa linha constante $[\ldots]$ : a descrição do choque de culturas" $(84,85)$. Debemos reparar que

1 "La mayoría de la crítica ha puesto a Antropofagia en el paradigma de la síntesis, y se la asimila aunque no siempre de manera expresa- a lo que Fernando Ortiz llamó transculturación (1940). [...] Tanto Antropofagia como la transculturación habrían servido como metáforas modélicas de integración entre la cultura nacional vernácula y los impulsos modernizadores e influencias "externas" (como en el ars combinatorio de Ángel Rama); ambos tropos habrían funcionado como herramientas discursivas de identificación y auto-percepción cultural en la modernidad; y ambos, definirían el papel del intelectual como agente cultural modernizador o mediador (antropófago, transculturador, traductor cultural, etc.)" (Jáuregui, Canibalia 429). Haroldo de Campos, por ejemplo, sostiene que con Antropofagia se piensa dialógicamente lo nacional como una "transculturação; melhor ainda, uma "transvaloração" ("Da razão antropofágica" 11). Para Augusto de Campos Antropofagia constituye "a única filosofia original brasileira e, sob alguns aspectos, o mais radical dos movimentos literários que produzimos" (Poesia ... 124). Silviano Santiago ve en ella una suerte de desautorización de la distinción jerárquica del "original" frente a la copia y del centro frente a la periferia $(20,26)$. Eloisa Barbosa y Lia Whyler arguyen que Antropofagia es una teoría latinoamericana de la traducción (326-332).

2 Roberto Fernández Retamar corrige su ensayo Calibán (1971) incluyendo a Andrade en la lista de Calibanes de su genealogía intelectual. Como él mismo señaló en "Calibán ante la Antropofagia” (2000): "en 1971 yo desconocía aún su obra [...]. Cuando empecé a familiarizarme con la faena del brasileño, lo incorporé en mis páginas" (Concierto para la mano izquierda 140).

3 Antropofagia ha sido caracterizada como estrategia "mímica" y de impugnación (pos)colonial de la cultura hegemónica (à la Homi Bhabha) que anticiparía el valor emancipador de la "cita" y la "reinscripción" - como modos culturales de lo postcolonial. Antropofagia es frecuentemente mencionada como una propuesta contra-colonial o de descolonización y un intento de emancipación cultural frente al eurocentrismo y el colonialismo (véase por ejemplo Víctor Rodríguez Núñez 1095-1109; Giuseppe Cocco 57-74; Else Vieira 95-113). Eduardo Viveiros de Castro sostiene que la "antropofagia oswaldiana" es "a reflexão metacultural mais original produzida na América Latina até hoje. A antropofagia foi a única contribuição realmente anti-colonialista que geramos” (25). Lúcia Sá juzga que "Andrade transformed Tupi ritualistic cannibalism into a statement of postcolonial cultural appropriation" (xx). Igualmente, Lesley Wylie indica que en Antropofagia el canibalismo es un proceso cercano al reciclaje, la criollización y la parodia de tropos imperiales "to produce the founding fictions of the postcolonial nation" y arguye que esas estrategias "resemble techniques in postcolonial writing outside the Americas. Bhabha for instance" (16, 17). Hasta se ha incluido el "Manifesto Antropófago" de Andrade en un "reader" de poscolonialismo editado por Diana Brydon al lado de Aimé Césaire y Frantz Fanon (409417). El mismo criterio usa Maria Luisa Nunes en "Whole: Literary strategies of decolonization in the works of Jean Rhys, Frank Fanon and Oswald de Andrade."

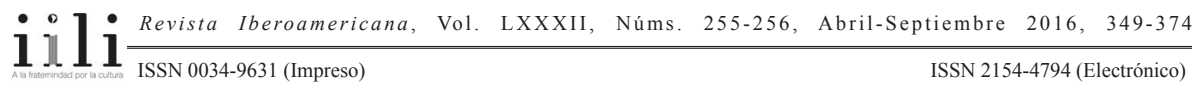


Antropofagia, en su fase modernista, ${ }^{4}$ fue menos un movimiento con unidad de mensaje y propósito que un polisémico collage textual, avant-gardiste, paródico, fragmentario y antiacadémico, promovido desde la élite cafetera en la coyuntura de una modernización periférica y en el espacio restringido de una esfera pública burguesa. Sus discursos contra la propiedad privada estaban patrocinados por acaudalados propietarios; ${ }^{5}$ la bárbara cena antropófaga consistía a menudo en una forma de consumo periférico de la alta cultura, y la des-occidentalización propuesta era estética y la mayoría de las veces francamente occidentalista (Jáuregui, Canibalia 22-28).

Por supuesto que toda generalización invita excepciones; aunque se tiende a identificar Antropofagia con Oswald de Andrade, el movimiento estuvo integrado por un heterogéneo grupo de escritores y artistas tales como Tarsila do Amaral (18861973) -verdadera iniciadora del movimiento de Antropofagia ${ }^{6}$-, Mario de Andrade (1893-1945), Raul Bopp (1898-1984), Antônio de Alcântara Machado (1901-1935), Augusto Frederico Schmidt (1906-1965), Menotti del Picchia (1892-1988), Benedito Geraldo Ferraz Gonçalves (1903-1979) y Oswaldo Costa (1900-1967), uno de los más originales antropófagos modernistas.

Oswaldo Costa representa -incluso mejor que Andrade- lo que podríamos llamar de manera retrospectiva el contra-colonialismo culturalista del modernismo brasileño. Este ensayo revisita, en el heterogéneo acervo de Antropofagia, ciertas contribuciones de

\footnotetext{
4 Antropofagia no se reduce a su momento modernista; por el contrario, representa un tropo recurrente en la literatura, la cultura popular, las artes plásticas, la música y la teoría cultural de las últimas cinco décadas. Piénsese, por ejemplo, en el Concretismo, Tropicália y el Cinema Novo de los 60 y 70 . (v. Perrone, Jáuregui). Antropofagia es contemporáneamente retomada en obras de teatro, novelas, eventos culturales, la plástica, y la crítica cultural. José Teixeira Coelho Netto expresa el cansancio, sentido por varios críticos culturales, con la que él denomina la "monomanía" de la Antropofagia como "mito fundador da cultura brasileira contemporânea" y por su esquematismo y vacuidad; Coelho resiente la alusión repetitiva del tropo cultural antropofágico que normalmente viene acompañada de su sinsentido actual (219-23).

5 La ruptura modernista como señala Nelson Sodré -era una ruptura "sob proteção das representações mais consagradas do regime, as mais austeras, as mais conservadoras" (História da literatura brasileira 525).

6 La frecuente identificación de Antropofagia con un solo autor, Oswald de Andrade, desplaza a un lugar accesorio a otros partícipes, como Tarsila do Amaral, quien -justo sea decirlo- propone de manera plástica el primer manifiesto antropófago con su óleo sobre tela Abaporu (1928). Dicho cuadro inspiró a Andrade y a otros modernistas a fundar el movimiento. Según Aracy Amaral, Tarsila regaló Abaporu a Andrade para su cumpleaños (enero 11 de 1928). Como se sabe, abaporu quiere decir antropófago en lengua tupí y viene de $a b a$ (hombre) y poru (que come). Abaporu imponía la presencia de un cuerpo desnudo y voluminoso con una cabeza pequeñísima sobre un fondo azul, al lado de un cactus. De la imagen de este caníbal sensual y desnudo, con la cabeza disminuida pero en la postura de "El pensador" de August Rodin (Le Penseur 1882), surge la propuesta de hacer un movimiento que recuperara de manera afirmativa la imagen colonial de Brasil como una tierra de caníbales (Jáuregui, Canibalia 410). Tarsila retornará este tema pictórico en su ilustración del "Manifesto Antropófago" (1928) y en un óleo de 1929 titulado Antropofagia.
}

$111 \frac{\text { Revista Iberoamericana, Vol. LXXXII, Núms. 255-256, Abril-Septiembre 2016, 349-374 }}{\text { ISSN 0034-9631 (Impreso) }}$ 
Oswaldo Costa, que-como veremos-articularon unaAntropofagia-otra, intelectualmente trabada en la crítica de la cuestión colonial y del Occidentalismo.

\section{Oswaldo Costa, El gRAN OLVIDADO}

Oswaldo Costa (1900-1967) fue uno de los más asiduos colaboradores de la Revista de Antropofagia y una figura en su tiempo central del movimiento. Pero pese a haber sido uno de sus líderes y haber llevado Antropofagia a sus más radicales propuestas, Costa permanece perdido en los recovecos de la indiferencia crítica y de la amnesia de la historiografía literaria. Los principales estudios sobre las vanguardias latinoamericanas y el modernismo brasileño apenas lo mencionan. Costa es una figura borrosa para expertos del calibre de Antônio Cândido y Maria Eugenia Boaventura. ${ }^{7}$ Algunos críticos como Vicky Unruh y Robert Stam creen incluso -equivocadamente- que Oswaldo Costa era uno de los pseudónimos de Oswald de Andrade. ${ }^{8}$ Costa devino el vestigio borroso de una desaparición; un espectro literario que se confunde con su colega y cuasi-tocayo Andrade.

Oswaldo Costa (quien en ocasiones se firmó Osvaldo, con v) nació en Belém do Pará en 1900 y murió el 12 de mayo de 1967 en Rio de Janeiro. ${ }^{9}$ Costa llegó a Rio en 1918, donde al parecer hizo estudios de derecho. Prontamente inició su carrera periodística como redactor en el Correio da Manhã. A mediados de la década de 1920 se acercó a los modernistas de São Paulo, y en 1928 se unió al movimiento de Antropofagia del cual fue uno de sus fundadores.

Como se sabe, la Revista de Antropofagia tuvo dos épocas o “dentições." La primera, de mayo de 1928 a febrero de 1929 publicó 10 números, editados mensualmente $\left(R A 1^{\mathrm{a}}\right)$. La segunda, fue una página (suplemento) del Diário de São Paulo y tuvo 16 entregas

Amablemente Telê Porto Ancona Lopez consultó en mi nombre a Antônio Cândido sobre Costa (julio 2000). Cândido, que lo conoció personalmente, lo recuerda y describe como un poco bajo y gordo; vehemente y siempre hablando de política: "no sé que pasó con él. Una de sus hijas fue bibliotecóloga de la facultad de economía de la USP... la otra, una actriz de teatro famosa que ya todo el mundo olvidó. Se ha cometido una injusticia con Costa, el gran olvidado." Ciertamente Cândido mismo contribuyó a este olvido, extrañándolo de sus historias de la literatura brasileña y de sus análisis del modernismo. Maria Eugenia Boaventura, la crítica que mejor conoce la Revista y en general los textos del modernismo antropófago, señala: "Não sei muita coisa também sobre Oswaldo Costa. Apenas que foi amigo de Oswald e ligado ao Partido Comunista depois de 1930” (Comunicación personal, abril 24, 2004).

8 Vicky Unruh cree que Costa es un seudónimo de Andrade (notas 11 y 13 del capítulo 3, 272, 273); Robert Stam sostiene la misma hipótesis: “'Oswaldo Costa,' [is] in all probability a pseudonym for Oswald de Andrade" (249).

9 La información biográfica disponible sobre Oswaldo Costa es sorprendentemente escasa. Los pocos datos que aquí se ofrecen no pretenden apoyar una hermenéutica textual sino presentar a un antropófago prácticamente desconocido. 
publicadas más o menos cada semana del 17 de marzo al 1 de agosto de $1929(R A$ $2^{\mathrm{a}}$ ), cuando el Diário de São Paulo decidió su clausura. Costa participó en la primera etapa de la Revista bajo la dirección “ortodoxa” de Antônio de Alcântara; pero es en la segunda dentição cuando pasa a liderarla editorialmente. ${ }^{10}$ Como señaló el propio Andrade, Oswaldo Costa estuvo encargado junto con Raul Bopp de terminar con la línea ecléctica y moderada de Alcântara e impulsar la radicalización modernista de la publicación. En una carta a Carlos Drummond de Andrade de marzo de 1929, Oswald de Andrade llama a Costa "Cunhambebe auténtico" (Konyan Bebe), equiparando su liderazgo con el del famoso jefe caníbal tupinambá. ${ }^{11}$

En esta segunda etapa, Costa publicó numerosos textos con su nombre y usando varios seudónimos (como Tamandaré), e instituyó la irreverente columna "Moquém". Jayme Adour da Câmara (1898-1964), codirector de la Revista de Antropofagia en su segunda etapa, llamó a Costa "seu maior teorizador" (3), y Bendito Geraldo Ferraz (1903-1979), secretario de la Revista, aseguraba que la segunda dentição se sostuvo gracias al liderazgo de Costa, quien fue su verdadero editor y quien con sus “"moquéns” teorizadores" le dio la base intelectual al "asado antropofágico". ${ }^{12}$ Confirma la prominencia de este Konyan Bebe teorizador, además, su inclusión en el proyecto de la "Bibliotequinha Antropofágica" que iba a incluir entre otros textos: Macunaíma (1928) de Mário de Andrade, Cobra Norato (1931) de Raul Bopp, el Manifesto Antropófago de Andrade (1928), y una obra de Costa titulada Moquêns e pontas-de-flecha, que hubiera reunido sus contribuciones a la Revista (Bopp, Vida y muerte 36; Cobra Norato 9). El proyecto nunca se llevó a cabo, pues Antropofagia se disolvió después del cierre de la

${ }^{10}$ En una entrevista poco antes de su muerte, Andrade reitera el contraste entre las dos dentições: "A revista não foi uma. Foram duas. A primeira, em cuja supervisão ficara Alcântara Machado, surgiu com um caráter eclético, que desnecessário dizer, desagradou profundamente a parte de nosso grupo [...]. Baste dizer que até Plínio Salgado andou deitando por lá sua pobre cienciazinha... Foi aí que resolvemos tomar de assalto o suplemento do Diário de São Paulo" (Os dentes do dragão 213).

11 Refiriéndose a la primera dentição o etapa de la Revista de Antropofagia, Oswald indicaba: "não houve transformação e sim ortodoxia. O Alcântara não entendeu o sentido do movimento. Pensou que era troça e publicou durante meses inutilidades amenas. Evidentemente errei em tê-lo convidado para dirigir a Revista de Antropofagia." Esta situación, habría cambiado durante la segunda dentição: "Agora a cosa é outra-le escribe Oswald a Carlos Drummond-. Estão à frente Bopp e Oswaldo Costa, cunhambebes autênticos e leais" (Drumond 101).

12 "Baixo, moreno, muito escanhoado, o editorialista do Correio Paulistano [i.e., Costa], não se demorava em considerações; era muito objetivo e quando falava liquidava qualquer questão que estava na mesa de discussões do comité da redação. Era ele quem expressava as resoluções e fazia uma crítica séria, como si se tratasse de uma publicação muito orientada [...]. Osvaldo Costa é que dera a base ao asado antropofágico, nos "moquéns" teorizadores, que começou a publicar. [...] E "moquém" celebrizou-se através da teorização acre de Osvaldo Costa" (Ferraz 52, 53). En una entrevista Ferraz señala que Costa fue "uma figura importante e preponderante, que explorou a maior parte do 'negócio' e mais por sua causa foi mantida a segunda fase" (Boaventura, A vanguarda antropofágica 206).

$111 \frac{\text { Revista Iberoamericana, Vol. LXXXII, Núms. 255-256, Abril-Septiembre 2016, 349-374 }}{\text { ISSN 0034-9631 (Impreso) }}$ 
Revista, en medio de rencillas personales y de la crisis que siguió al colapso bursátil de 1929 , la ruina de la oligarquía paulista y el ascenso al poder del populismo nacionalista (Getúlio Vargas).

Oswaldo Costa regresó a Rio de Janeiro y dejó las "Bellas Letras" para dedicarse al periodismo y la política. Durante la década de 1930, participó en numerosas actividades antifascistas y de izquierda; apoyó el Comitê Antiguerreiro do Rio de Janeiro y fue miembro de la Dirección del Partido Comunista. ${ }^{13}$ En 1934 fundó junto con Apparício Torelly (1895-1971) y Aníbal Machado (1894-1964) -compañero de Antropofagia-el efímero Jornal do Povo (octubre 1934). ${ }^{14}$

En noviembre de 1935, Costa -entonces periodista de $A$ Manhã - participó en la insurrección comunista contra Getúlio Vargas conocida como la "Revolta vermelha" o "A intentona," por lo que a mediados de agosto de 1936 fue capturado y acusado de rebelión. Las autoridades lo consideraban el "secretario intelectual" del partido. ${ }^{15}$ El 4 junio de 1937, Costa fue puesto en libertad mientras proseguía el juicio en su contra; ${ }^{16}$ lo que él aprovechó para pasar a la clandestinidad. El Tribunal de Segurança Nacional lo sentenció a tres años y cuatro meses de prisión (junio 28, 1937). ${ }^{17}$ Por entonces, dejó su alias "Ramalho" y re-adoptó el pseudónimo modernista "Tamandaré." Prófugo, Costa se encargaba de los comunicados y propaganda del Partido. En 1940, los operativos de búsqueda se recrudecieron; Costa fue delatado por uno de sus compañeros, pero logró escapar de una redada policial y refugiarse en la Embajada de Chile. Poco después se entregó y renunció públicamente al partido: "Termino aqui -le dice a un reportero-a minha ação revolucionaria com um infinito desencanto" (Diário da noite abril, 23 de 1940:3). Costa fue condenado a cinco años de cárcel de los cuales aparentemente cumplió dos. ${ }^{18}$ En 1942 fue excarcelado y se incorporó a la revista de izquierda Diretrizes. ${ }^{19}$

${ }_{13}$ Ferraz recuerda que Costa "Esteve no Partido, participou do Partido. Andou sendo perseguido, fugindo e, não sei por que, foi parar no Rio de Janeiro. [...] Ele já faleceu" (Boaventura, $A$ vanguarda antropofágica 209). Véase también Figueiredo de Castro $(359,381)$ y Soares dos Santos $(410)$.

${ }^{14}$ El Jornal do Povo cerró cuando Torelly fue secuestrado y amenazado de muerte por oficiales de la marina. Esta aventura periodística post-Antropofágica de Oswaldo Costa recuerda la similar de Oswald de Andrade y Patrícia Galvão (1910-1962) quienes fundan y editan el también fugaz O Homem do Povo (1931).

${ }_{15}$ Correio da Manhã, agosto 14 de 1936: 8; Gazeta de noticias, julio 16 de 1936: 12; agosto 15 de 1936: 7; Correio da Manhã, noviembre 25 de 1936: 3, 5; diciembre 16 de 1936: 7; febrero 24 de 1937: 3; marzo 20 de 1937: 7.

${ }_{16}$ A Batalha junio 25 de 1937: 2; Correio da Manhã junio 8 de 1937: 12.

17 Correio da Manhã julio 29 de 1937: 3; Gazeta de Noticias, agosto 29 de 1937: 3. Costa apela la sentencia mediante apoderado pero ésta es confirmada en enero de 1938 (A Batalha, enero 15 de 1938: 2; Gazeta de Noticias, enero 15 de 1938: 3).

18 A Noite abril 23 de 23 de 1940, 1, 3; Correio da Manhã, abril 23 de 1940: 3; Diário da noite, abril 23 de 1940: 3, 6; Diário de noticias, abril 23 de 1940: 1; abril 26 de 1940: 3.

19 A Manhã, enero 8 de 1942: 13; Diretrizes, abril 2 de 1942: 5. 
Como se dijo, Oswaldo Costa dedicó gran parte de su vida al periodismo como redactor y colaborador de numerosas publicaciones entre las que se cuentan Diário da Bahia, Correio da Manhã, Correio Paulistano, la sucursal de la Folha de São Paulo en Rio, la Revista de Antropofagia, el Jornal do Povo, A Manhã, la mencionada revista Diretrizes (de la que fue nombrado director en 1945) y, de manera destacada, el periódico O Semanário (1956-1964) fundado y dirigido por él. O Semanário llegó a tener un tiraje nacional de sesenta mil ejemplares, siendo una de las mayores publicaciones del período en el Brasil (Sodré 409; Brito, "O Semanário" 1-15). O Semanário fue cerrado por la dictadura militar el 1 de abril de 1964. Costa fue sometido con su esposa Leonor a una investigación militar y el gobierno le suspendió sus derechos políticos. Entonces, intentó su última aventura periodística: la publicación clandestina del Jornal Semanal, del cual salieron tres números de cuatro páginas cada uno. A principios de mayo de 1967, cuando Costa se preparaba a viajar a Europa, murió de un ataque cardiaco en plena calle. ${ }^{20}$ Ese mismo año comenzó la canonización de Andrade y el olvido Costa. ${ }^{21}$

\section{2. "A 'Descida' AntropophagA"}

“A 'Descida' Antropophaga” de Oswaldo Costa, que apareció en el primer número de la Revista de Antropofagia junto con el "Manifesto" de Andrade, es un texto que puede ser llamado sin temor a exagerar el otro manifesto antropófago ( $R A, 1^{\mathrm{a}}$, num. 1 : 8). Allí -así como en varias de sus colaboraciones en la segunda dentição- el escritor modernista pone en tela de juicio la adscripción de Brasil a Europa, lee la historiografía del Brasil en contra de su celebración explícita e implícita del colonialismo y plantea la necesidad de una descolonización cultural antropofágica.

“A 'Descida' Antropophaga" es un texto propenso antes que a la argumentación sistemática, a la alusión minimalista (casi telegráfica) y a la de-familiarización surrealista. ${ }^{22}$ Costa comienza su manifiesto mediante un extrañamiento del significante "descida" (i.e., descenso), siempre entre comillas: “A 'descida' agora é outra. [...] Ha quatro seculos, a 'descida' para a escravidão. Hoje, a ‘descida’ para libertação." "Descida” tiene un doble sentido: la primera "descida" de hace "cuatro siglos" es la colonización que fuerza a los indios a salir de la selva, dejar el canibalismo e incorporarse en la colonia (descerse para as aldeias); esto es, el sometimiento y reducción a poblados de los pueblos

20 Jornal do Brasil mayo 13 de 1967, 16; Diario de noticias mayo 17 de 1967, 2a seção: 3.

21 El interés sobre Andrade y su subsecuente canonización ocurre en gran medida gracias al estreno de su obra teatral O rei da vela (1937) dirigida por José Celso Martinez Corrêa (septiembre 1967) (Jáuregui, Canibalia 411-12, 450-53).

22 También el "Manifesto" de Andrade es un texto anti-racionalista y paradójico que antes que proposiciones ofrece digresiones poéticas y oraciones surrealistas (Jáuregui “Antropofagia” 22-28; Luís Madureira 1333). 


\section{A "Descida" Antropophaga}

A "descida" agora é outra. $O$ Autor

Ha quatro seculos, a "descida" para a escravidão. Hoje, a "descida" para libertaçắo. O Diluvio, foi o movimento mais serio que se fez no mundo. Deus apamovimento mais começar de novo. Foi intelligente, pragou tudo, para começar de novo. Foi intelligente, pratico e natural. Mas teve uma fraqueza: deixou Noé. O movimento antropophago, - que é o mais serio
ois do Diluvio - vem para comer Noé. NOE' DEVE SER COMIDO.

Penso que não se deve confundir volta ao estado natural (o que se quer) com volta ao estado primitivo (o que não interessa). O que se quer é simplicidade e (o que não interessa). O que se quer Naturalidade, não não um novo codigo de simplicidade. Naturalica, a belmanuaes de bom tom. Contra a belleza canonica, a bel feia, bruta, agreste, barbara, illogica. Instincto contra o verniz. O selvagem sem as missangas da cathechese. O selvagem comendo a cathechese. Os PEROS que ainda existem entre nós hâo de sorrir por seus dentes de ouro o sorriso civilisado de que, reagindo contra a cultura, estamos dentro da cultura. Que besteira. O que temos não é cultura européa é experiencia della. Experiencia de quatro seculos. péa: é experiencia della. Experiencia canal de Veneza julgamento synthetico a priori, Tobias, Nabuco e Ruy. julgamento synthetico a priori, Tobias, O que fazemos é reagir contra a civilisação que inventou o catalogo, o exame de consciencia

floramento. SOMOS JAPY-ASSU": "Ce venerable vieillard Japi Ouassou fut merveilleusement attentif, comme tous les outres Inciens lá presens aux discours susdicts á quoi il replique ce qui s'ensuit. Je m'esionis extremement de vous voir et me manqueray á tout ce ie vous ay promis. Mais ie me estonne comme il se peut faire que vous autres PAY ne vouliez pas de femmes. Estes vous descendus du Ciel? Estes nays de Pere et Mere? Quay donc! n'estes pas Estes nays de Pere et Mere? Quay donc! n'estes pas
mortels comme nous? D'ou vient que non seulement mortels comme nous? D'ou vient que non seulement
vous ne prenez pas de femmes ainsi que les autres Francois que ont trafiqué avec nous depuis quelque quarante et tant d'années; mais ancore que vous les empechez maintenant de se servir de nos filles: ce que nous estimions a grand honeur et grandheur, pouvans en avoir des enfans".

(Claude d Abbeville-"Histoire de la Mission des Péres Capucins en l'Isle de Maragnan et terres circonvoicines.")

Contra o servilismo colonial, o tacape inheiguára "gente de grande resoluçâo e valor e totalmente impaciente de sujeição" (Vieira), o heroismo sem rospta de Commendador dos carahybas, "que se oppuzeram a que Diogo de Lepe desembarcasse, investindo contra as caravelas e reduzindo o numero de seus tripulantes" (Santa Rosa - "Historia do Rio Amazonas").

Ninguem se illuda. A paz do homem americano
Nastoria do Rio Amazonas"). Ninguem se illuda. A paz do homem americano
a civilisação européa é paz nheengahiba. Está no com a civilisação européa é paz nheengahiba. Está no passava de uma verdadeira impostura, continuando os barbaros no seu antigo theor da vida selvagem, dados a antropophagia como dantes, e baldos inteiramente da luz do evangelho."

Como se vê, facthmo ser antropophago. Basta eliminar a impostura.

Foram estas as consequencias dos versos ruimzizinhos que Anchieta escreveu na areia de Itanhaeń Ordenações do Reino, grammatica e ceia de Da Vinci na sała de jantar. E não houve ainda quem comesse Anchieta!
Portugal vestiu o selvagem. Cumpre despil-o. Para que elle tome um banho daquella "innocencia contenque elle tome um banho daquella "innocento a the restitue. O homem, (falo o homem europeu, cruz the restitue. credo!) andava mão: philosophia.

Nós queremos o homem sem a duvida, sem siquer Nós queremos o homem semuida: nú, natural, antropophago.

Quatro seculos de carne de vacca! Que horror!

(a) OSWALDO COSTA.

\section{VISITA DE SÃO THOME'}

Quando a Bahia não se chamava Bahia, muito antes de Pedro Alvares Cabral, São Thomé foi lá um dia.

Não sei se foi por acaso ou para vêr. Mas viu.

Viu e protestou contra as coisas que viu.

Fez um discurso cheio de conselhos que os indios escutaram de boccas abertas:

Que era preciso adorar a Deus, fugir do de monio, não ter mais que uma mulher. Conselhos bons.

Emquanto falava, fazia nascer da terra a planta da mandioca e a bananeira que ainda hoje dá bananas de São Thomé.

Então os indios gostaram.

Quando São Thomé, cansado, sentiu que devia acabar, acabou com estas palavras:

-E não comam nunca mais carne de gente!

Então os indios não gostaram. Avançaram.

Quizeram comer o santo.

Felizmente São Thơmé corria mais do que elles.

Chegou na beira da praia, deu um passo de meia legua e foi parar numa ilha onde não tinha selvagens.

(Quem me ensinou isto foi Frei Vicente do Salvador...)

\section{ALVARO MOREIRA.}

\section{NOTA INSISTENTE}

Neste rabinho do seu primeiro numero a "Revista de Antropofagia" faz questão de repetir o que ficou dito lá no principio

- Ella está acima de quaesquer grupos ou tendencias:

- Ella acceita todos os manifestos mas não bota manifesto; critica;

- Ella acceita todas as criticas mas não faz

- Ella é antropofaga como o avestruz é comilão;

- Ella nada tem que ver com os ponros de vista de que por acaso seja vehiculo.

A "Revista de Antropofagia" não tem orientação ou pensamento de especie alguma: só ten estomago.

A de A. $M$.

R. B. 
indígenas brasileños desde el siglo XVI hasta bien entrado el XIX. Estas expediciones en búsqueda de indios para reubicarlos en pueblos y misiones -y eventualmente en las haciendas- fueron llamadas descimentos de índios, dado que éstos eran traídos río abajo; es decir, bajando por los ríos desde el interior. A su vez, a los indígenas domeñados se les llamó índios descidos. Pero el manifiesto declara que "A 'descida' agora é outra;" no la que estableció la esclavitud, sino "a 'descida' para libertação;" es decir, el descenso de los caníbales sobre la civilización, no para someterse a ella sino para someterla (devorarla), en el mismo sentido que se dice que una ave de rapiña desce sobre a presa. Esta nueva "descida" antropófaga permitiría comenzar de nuevo y cancelar la condición occidental de Brasil. De allí, que Costa afirme humorísticamente que, después del diluvio, Antropofagia fue el movimiento más serio que se hizo en el mundo: "Deus apagou tudo, para começar de novo. Foi intelligente, [...]. Mas teve uma fraqueza: deixou Noé. O movimento antropófago-que é o mais serio depois do Dilúviovem para comer Noé. NOÉ DEVE SER COMIDO” (“A 'Descida' Antropophaga” 8; énfasis y mayúsculas en el original). Este recomienzo postdiluviano requiere según Costa una mirada antropofágica sobre la supuesta pertenencia de Brasil a Occidente y la re-lectura digestiva de la historiografía nacional para subrayar no el triunfo colonial sino la resistencia contra-colonial, no la conversión sino la obstinación de la alteridad, no la "descida" civilizatoria, sino la "descida" Antropófaga.

Costa enfila baterías contra la concepción de la cultura brasileña como europea y cuestiona su modernidad y adscripción occidental(ista):

Os PEROS que ainda existem entre nós hão de sorrir por seus dentes de ouro o sorriso civilisado de que, reagindo contra a cultura, estamos dentro da cultura. Que besteira. $O$ que temos não é cultura européa: e experiencia dela. Experiencia de quatro séculos. Dolorosa e páo. Com Direito Romano, canal de Veneza, julgamento synthetico a priori, Tobias, Nabuco e Ruy. O que fazemos é reagir contra a civilização que inventou o catalogo, o exame de consciencia e o crime de defloramento. SOMOS JAPY ASSU (“A ‘Descida' Antropophaga” 8; énfasis mío, mayúsculas y negritas en el texto).

El texto hace explícito el mal-estar cultural al que se refiere Roberto Schwarz: "brasileiros e latino-americanos fazemos constantemente a experiência do caráter postiço, inautêntico, imitado da vida cultural que levamos [...], sentimento da contradição entre a realidade nacional e o prestígio ideológico dos países que nos servem de modelo" ("Nacional por subtração" 29-30). Para Costa, la experiencia de pertenecer a Occidente corresponde en Brasil a cuatro siglos de colonialismo intenso y de imposición normativa, estética y filosófica. El derecho romano, una suerte de fetiche de los estudios jurídicos en Brasil, así como el pensamiento de Kant, recitado de manera acrítica en las facultades de

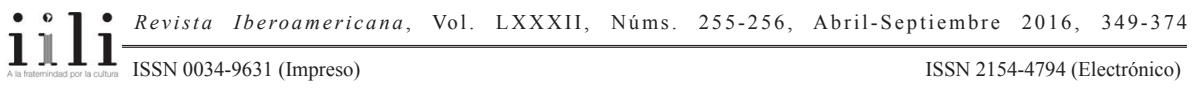


filosofía, ejemplifican para Costa tanto la incómoda inscripción de Brasil en Occidente, ${ }^{23}$ como la complicidad intelectual con el colonialismo de "Os PEROS [eurocéntricos] que ainda existem entre nós." Costa extiende estas críticas a los propios modernistas y se burla del europeísmo de ni más ni menos que Anita Malfatti (1889-1964), ícono de la primera generación modernista. ${ }^{24}$ Costa alude a uno o acaso dos cuadros de Malfatti en los que la pintora parece retractarse de la radicalidad modernista de 1922: Canaletto (Veneza) (Salon d'Automne, Grand Palais, Paris, 1924) y Canal grande de Veneza (ca. 1927). ${ }^{25}$ Hay en Oswaldo Costa una conciencia temprana del eurocentrismo y elitismo de la revolución modernista. ${ }^{26}$ Más adelante designará este tipo de complicidad como mentalidade reinol: "o mal dos nossos escritores é estudar o Brasil do ponto de vista falso, da falsa cultura e da falsa moral do ocidente. A mentalidade reinol, de que não se libertaram, é o que os leva a esse erro" ("Revisão necessária" 1). En su columna Moquém, Costa explicaba que el Modernismo

ficou no acidental, no acessório, limitou-se a uma simples revolução estética-cosa horrível-quando sua função era criar no Brasil o pensamento novo brasileiro. [...] Continuamos, ainda depois, escravos de Ocidente, escravos do catolicismo, escravos da cultura européa caindo de pôdre. [...] A nossa historia continuo a ser escrita com as patranhas dos padres [...]. Pensamento novo não creamos. Continuou o pensamento velho de importação. Comido pela broca do Ocidente. O grande erro dos modernistas foi esse. A preocupação estética exclusiva. [...] Eles não compreenderam que todo era preciso vir abaixo. A falsa arte. A falsa [h]istoria. [...] Não compreenderam as cruzadas, as guerras, as lutas econômicas. [...] Aceitaram uma porção de fórmulas idiotas: que isto é civilização; e aquilo é progresso. ("Moquem II: Hors de œuvre" 5)

El modernismo no simplemente habría respondido sino que se habría plegado a una suerte de eurocentrismo ontológico, sometiéndose a la(s) historia(s) de los vencedores y a las fórmulas de la civilización y el progreso. Costa impugna antropofágicamente

${ }^{23}$ Nótese la referencia burlona a la tradición de juristas como Joaquim Nabuco, Tobias Barreto y Ruy Barbosa, así como al kantiano juicio sintético a priori.

${ }^{24}$ Como se recordará, en 1917 varios jóvenes escritores defendieron la obra pictórica de Malfatti frente a las críticas conservadoras de Bento Monteiro Lobato (1882-1948). Este debate propició entre los jóvenes modernistas un espíritu de grupo y un deseo de sincronía cultural con la Modernidad europea que se concretó más tarde en la Semana de Arte Moderna de 1922.

${ }_{25}$ Costa alude a estos cuadros probablemente sin haberlos visto y conociéndolos sólo por referencia (de Mario de Andrade). Malfatti regresa a São Paulo en septiembre de 1928 y exhibe en dicha ciudad ambos cuadros en su Muestra individual en febrero de 1929.

26 Antropofagia -como el arielismo- se mantiene en el universo gutemberguiano y en una esfera pública letrada; valga la pena mencionar que Oswald de Andrade se manifestó, bajo el pseudónimo de Freuderico a favor de la alfabetización (Costa, "De Antropofagia" 1).

$111 \frac{\text { Revista Iberoamericana, Vol. LXXXII, Núms. 255-256, Abril-Septiembre 2016, 349-374 }}{\text { ISSN 0034-9631 (Impreso) }}$ 
estas fórmulas así como la historiografía occidentalista sobre la que éstas descansan. ${ }^{27}$ La frase "SOMOS JAPY ASSU" (irónica, enfática y en mayúsculas) de "A 'Descida'..." reitera la queja de Costa frente al vasallaje o servilismo cultural nacional. Japy Assu es el cacique colaborador de la aldea Juniparã que da la bienvenida a los misioneros capuchinos franceses en Maranhão en $1612 .{ }^{28}$ El cacique promete cristianizarse y ofrece sus mujeres a los frailes quienes rechazan el regalo. Desconcertado, Japy Assu, como tantos otros salvajes oradores del imaginario colonial europeo, lanzó un famoso discurso a los capuchinos, que Costa cita en francés de la crónica de Claude d'Abbeville (1614):

Ce venerable vieillard Japi Ouassou fut merveilleusement attentif, comme touts les outres Indiens lá presens aux discours susdicts á quoi il replique ce qui s’ensuit. [“]Je m'esionis extremement de vous voir et me manqueray á tout ce ievous ay promis. Mais ie me estonne comme il se peut faire que vous autres PAY ne vouliez pas de femmes. Estes vous descendus du Ciel? Estes nays de Pere et Mere? Quay donc! n'estes pas mortels comme nous? D'ou vient que non seulement vous ne prenez pas de femmes ainsi que les autres François que ont trafiqué avec nous depuis quelque quarante et tant d'années; mais ancore que vous les empechez maintenant de se servir de nos filles: ce que nous estimions a grand honneur et grandheur, pouvans en avoir des enfant.["] (d'Abbeville citado por Costa, "A 'Descida' Antropophaga” 8) ${ }^{29}$

A partir de esta escena colonial de oferta de mujeres a un colonizador desganado, Costa se burla tanto del servilismo cultural brasileño como del triunfo sin consumar de la civilización. "Contra o servilismo colonial", Costa reclama otro tipo de bienvenida: la resistencia o reagir caníbal; frente al to be Japy Assu ("SOMOS JAPY ASSU"), propone el not to be de los aborígenes que se opusieron al colonialismo incluso cuando fueron aparentemente sometidos.

27 A diferencia de Costa, Oswald de Andrade por lo general se mostró entusiasta del progreso técnico y la industrialización del Brasil, tanto en los años 1920 como en sus tesis académicas de los cuarenta y cincuenta.

${ }^{28}$ Mientras que el indianismo romántico enaltece al indio colaborador (i.e., Iracema o Peri), Antropofagia se identifica simbólicamente con el indio indócil (Jáuregui, Canibalia 415).

29 Discurso registrado por el misionero capuchino Claude d'Abbeville en su Histoire de la mission des pères capucins en l'isle de Maragnan et terres circonvoisins. Se cita el fragmento en francés tal como aparece en el texto de Costa. A continuación una traducción del mismo: "El venerable anciano Japy-açú prestó mucha atención, como todos los demás indios allí presentes, y respondió de la siguiente manera: 'Estoy en extremo satisfecho de veros y nunca faltaré a mi palabra. Me sorprende mucho sin embargo que vosotros Pai no deseéis mujeres. ¿Descendisteis del cielo? ¿Nacisteis de padre y madre? ¿No sois mortales como nosotros? Y ¿por qué, además de no querer mujeres, a diferencia de los otros franceses que negocian con nosotros desde hace cuarenta y pico de años, vosotros ahora impedís que vuestros compañeros se sirvan de nuestras hijas, algo que nosotros consideramos un gran honor, por cuanto de ellos pueden tener hijos?'” 
Costa articula una crítica caníbal a la modernidad brasileña mediante ejemplos históricos de desafíos al colonialismo y de citas antropofágicas del archivo colonial:

Contra o servilismo colonial, o tacape inheiguára, "gente de grande resolução e valor e totalmente impaciente de sujeição" (Vieira), o heroismo sem roseta de Comendador dos carahybas, "que se opuseram a que Diogo de Lepe desembarcasse, investindo contra as caravelas e reduzindo o numero de seus tripulantes" (Santa Rosa - "Historia do Rio Amazonas"). Ninguém se iluda. A paz do homem americano com a civilização européia é a paz nheengahiba. (“A 'Descida' Antropophaga”; énfasis mío)

La propuesta de reagir (resistir) la civilización o la occidentalización del Brasil podría confundirse fácilmente con la definición de lo nacional por "subtração" -o eliminación de lo foráneo-según la célebre formulación del problema que hizo Roberto Schwarz, quien vio con escepticismo estas respuestas purgativas e inútiles al malestar de la influencia o a la condición periférica o "subdesarrollada" de la cultura nacional. Pero, como se verá, Costa no excluye sino que incorpora y resignifica, como en el caso de la cita en francés que hace de Claude d'Abbeville sobre el servilismo de Japy Assu. La resistencia al colonialismo que Costa propone -mediante el tropo del tacape y la parábola de la engañosa paz nheengahiba- no es purgativa sino definida por la noción de devoração antropofágica (o cita pérfida).

\section{3. "CONTRA O SERVILISMO COLONIAL, O TACAPE INHEIGUÁRA"}

El tacape o iwera pemme era un arma hecha de madera en forma de remo usada como garrote tanto en la guerra como en el sacrificio de prisioneros por numerosos pueblos indígenas brasileños. Dicha arma está directamente relacionada con el imaginario sobre el canibalismo bélico de los indios del Brasil desde comienzos del siglo XVI. Cuando Costa dice "Contra o servilismo colonial, o tacape inheiguára" invoca simbólicamente las luchas contra-coloniales indígenas, para (re)formular Antropofagia como una suerte de resistencia a, e incorporación de, Occidente. Como se dijo antes, la violencia que invoca el texto (tacape) no es sustractiva sino antropofágica (inheiguára).

Antes que adelantar una tesis, “A 'Descida'...” es, en sí, un ejercicio antropofágico. Costa devora al jesuita Antônio Vieira (1608-1697), quien entre 1653 y 1661 había predicado entre los indios de los actuales estados de Maranhão y Amazonas e iniciado la conquista espiritual de la región baja del Rio dos Tocantins. Costa transcribe "fielmente"a Vieira: "'gente de grande resolução e valor e totalmente impaciente de sujeição'(Vieira)". En efecto, el jesuíta menciona el valor de los indómitos inheiguáras en su carta al rey del 11 de febrero de 1660 sobre las misiones en Maranhão (Cartas 79); pero no lo hace de manera encomiosa, como Costa, sino para relatar la dificultad de la campaña de ocho meses de guerra y castigo contra los inheiguáras adelantada por el padre Manuel Nunes

$111 \frac{\text { Revista Iberoamericana, Vol. LXXXII, Núms. 255-256, Abril-Septiembre 2016, 349-374 }}{\text { ISSN 0034-9631 (Impreso) }}$ 
en 1658, en compañía de 450 indios aliados y 45 soldados portugueses. Los "rebellados" inheiguáras fueron-agrega el prelado-"buscados, achados, cercados, rendidos, e tomados quasi todos" como esclavos (Cartas 79). Costa cita a Vieira contra Vieira; alude no la victoria sobre los salvajes, sino a la resistencia y valor de los rebeldes; lee en contravía la historia triunfal católica y occidentalista, y desclausura la derrota de los buscados, hallados, cercados, rendidos... inheiguáras. Frente a los homenajes del nacionalismo brasileño a Europa y a la colonización, la antropofagia de Costa canibaliza el archivo histórico. No quiero decir que Costa tenga un proyecto benjaminiano de lectura de la historia, sino que pensando lo nacional, adelanta una crítica culturalista de las imágenes coloniales que informan el archivo histórico y simbólico de la nación.

Junto con la cita antropofágica de Vieira, Costa engulle también la História do Rio Amazonas (1926) ${ }^{30}$ de su coterráneo, el historiador y geógrafo Henrique Américo Santa Rosa. Santa Rosa era parte de la corriente académica geopolítica que en las primeras décadas del siglo XX estudiaba geografía física y humana para orientar la acción nacionalista del Estado respecto de sus políticas civilizatorias y de modernización. ${ }^{31}$ Santa Rosa es el historiador del proceso "civilizatorio" de la región amazónica que el colonialismo del siglo XVI inicia, y que el Estado debía completar en el siglo XX. El historiador-geógrafo reclamaba la presencia modernizadora estatal en la Amazonia. Dicho proyecto geopolítico de "civilização e progresso" coadyuvaba el expansionismo neocolonial y tenía - ciertamente-como uno de sus “problemas" el "asunto indígena." En el tratado de Santa Rosa los indios pertenecen, junto con algunos accidentes geográficos, al orden de las dificultades del proceso civilizatorio. Es en ese contexto que debemos releer la cita que Costa hace de Santa Rosa: "Contra o servilismo colonial, [...] o heroísmo sem roseta de Comendador dos carahybas, 'que se oppuzeram a que Diogo de Lepe desembarcasse, investindo contra as caravelas e reduzindo o numero de seus tripulantes' (Santa Rosa - 'Historia do Rio Amazonas')". ${ }^{32}$ Costa expropia, apropia y resignifica antropofágicamente la referencia de Santa Rosa contra la geopolítica neocolonialista del propio historiador-geógrafo.

La cita que Costa hace de Santa Rosa tiene que ver con la resistencia indígena a la expedición de Diego de Lepe (1460-1515), conquistador español que llegó al Brasil

\footnotetext{
30 Tesis presentada por Santa Rosa en el Congresso Internacional de História da América (1926).

31 “Circulava no Pará, os trabalhos de Friedrich Ratzel (1844-1904) e autores mais antigos como Friedrich Humboldt (1769-1859) e Carl Ritter (1779-1859), nomes então apontados como os pioneiros nos da geopolítica alemã, que mais tarde seria retomada por Karl Haushofer (1869-1946). Importante notar que tanto a geografia como a ciência política que se praticava então na Alemanha e na Suécia voltavam-se para a leitura do Estado como agente político fundamental na definição do espaço, do território e dos recursos naturais de uma nação. Em outras palavras, é possível afirmar que a geopolítica se consolidou, nas primeiras décadas do século XX, como o estudo da estratégia, da manipulação, da ação dos chamados Estados Nacionais" (Cardoso Moraes 1).

32 El texto citado se encuentra en la Historia do Rio Amazonas de Santa Rosa (121-22).
}

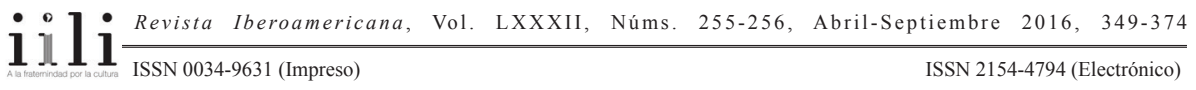


(probablemente al Cabo de São Agostinho en Pernambuco) a comienzos de febrero de 1500, antes de la expedición de Cabral (John Hemming 274, 275). Santa Rosa relata que los indios de Maranhão combatieron tenazmente a Lepe y mataron a once de sus hombres $(121,122)$. Costa invoca la heroicidad subalterna de los caraïbas: "heroismo sem roseta de Comendador" (i.e., sin la medalla de la Légion d'honneur), heroísmo anónimo, relegado al olvido por la Historia.

El procedimiento de incorporación textual de Vieira y de Santa Rosa es semejante: antropofágico y contra-colonial. Costa mastica el Occidentalismo que informa tanto al jesuita del siglo XVII como al geógrafo del XX. Con ambas citas destaca como fundamento histórico del imaginario nacional la resistencia a la evangelización, a la colonización y, en últimas, a las que él llamó "fórmulas idiotas" de la civilización y el progreso. Tal resistencia -permítasenos insistir- está figurada por el tropo caníbal y corresponde a un modelo de pensamiento digestivo, no sustractivo, de lo nacional, que desautoriza los discursos occidentalistas.

Otros textos de Oswaldo Costa llevan agua al mismo molino. En el número cuatro de la segunda dentição, Costa inaugura su columna "Moquém" (parrilla) reseñando (asando) el recién publicado Retrato do Brasil: ensaio sobre a tristeza brasileira (1928) de Paulo Prado (1869-1943). Prado era miembro de la aristocracia cafetera paulista y mecenas del modernismo brasileño desde 1922. Según Aracy Amaral, Prado culpó a Oswald de Andrade por el Moquém y lo dejó de tratar por el resto de su vida (302). Costa juzga que Retrato do Brasil es "ruim" y que Prado es un artista "romântico" y "piedoso" que cree en la "eternidade da arte" y en las "bons costumes portugueses"; un escritor, que se escandaliza con las costumbres sexuales de los indios, y que es "incapaz de devorar com prazer [...] uma canela do próximo." El mayor problema del libro de Prado según Costa es que se apoya acríticamente en la historiografía positivista decimonónica y en especial en João Capistrano de Abreu (1853-1927). Costa califica a Capistrano como un "archivista" que pretendía ser historiador del periodo colonial sin interesarse por la conquista, ni entender los procesos de resistencia y rebelión como parte de "nossa luta homérica de liberação". Así, escribe Costa, Prado se apoya en las "muletas da moral européa" echándole la culpa al oro y la lujuria por los "excessos infantis" de los brasileños. Más aun, Prado cita con una "ingenuidade pasmosa" y "como rigorosas verdades" las crónicas coloniales sin cuestionarlas ("Moquém I: Aperitivo" 4). La reseña del libro de Prado reitera la postura de "A 'Descida'..."; esto es: opone a la historiografía occidentalista (archivista y reproductora de la autoridad de los textos coloniales), una historiografía antropofágica que cita el archivo contra el archivo y la resistencia contra la conquista. 


\section{LA PAZ NHEENGAHIBA}

Oswaldo Costa se anticipa a la objeción de que él mismo escribe desde la cultura que censura: "Os PEROS que ainda existem entre nós hão de sorrir por seus dentes de ouro o sorriso civilisado de que, reagindo contra a cultura, estamos dentro da cultura. Que besteira" ("A 'Descida'...). Costa responde diferenciando la pertenencia cultural a Occidente de la experiencia periférica del Occidentalismo: dice que en el Brasil no se tiene una cultura europea sino una "experiencia della." De este modo, Costa entra en la crítica cultural de la Modernidad colonial vis-à-vis los proyectos periféricos de modernidades alternativas (como más tarde haría Enrique Dussel con su noción de transmodernidad). En otras palabras, Costa debate la razón occidentalista de la modernidad brasileña. La América europea (o europeizada) es la apariencia de un triunfo detrás del cual está un "selvagem comendo a cathechese"; un caníbal que lejos de ser asimilado resiste comiendo:

Ninguem se illuda. A paz do homem americano com a civilisação européa é paz nheengahiba. Está no Lisbôa: “aquella apparatosa paz dos nheengahibas não passava de uma verdadeira impostura, continuando os bárbaros no seu antigo theor de vida selvagem, dados á antropophagia como dantes, e baldos inteiramente da luz do evangelho.”

Como se vê, facílimo ser antropophago. Basta eliminar a impostura. (“A ‘Descida’...”8)

Ésta es para Costa la posibilidad caníbal: la diferencia o barbarie detrás de la pretensión engañosa de que América hace parte de Occidente: "Nadie se ilusione" pide Costa, pues la paz del hombre americano con la civilización europea es una impostura (o "paz nheengahiba"). Costa presenta como evidencia un fragmento de "Vida do padre Antônio Vieira no Brasil” (1853) del historiador decimonónico brasileño João Francisco Lisbôa (1812-1863), en el que éste relata los conflictos entre los colonos y los misioneros jesuitas que terminan con la revuelta de los primeros contra la Compañía de Jesús y su expulsión de Maranhão en 1661. Cuenta Lisbôa que hacia 1659 los colonos se quejaban de la "nullidade dos resultados colhidos pelas missões" y trae como ejemplo la "apparatosa paz dos nheengahides" (sic) (Obras 469). Este tratado de paz conocido como el "Acordo do rio Mapuá" (1659) fue gestionado por el padre Vieira para pacificar a los nheengahibas de la isla de Marajó (entre los ríos Tocatins y Pará). Éstos adelantaban una efectiva guerra de guerrillas contra los portugueses y se habían aliado con otros grupos indígenas y con los holandeses poniendo en jaque el dominio portugués. El jesuita consiguió que los nheengahibas hasta entonces rebeldes e "inconquistáveis," aceptaran "ser vasallos do rei de Portugal e ter paz perpetua e inviolável," vivir en poblados, y que no se unieran con los holandeses contra los

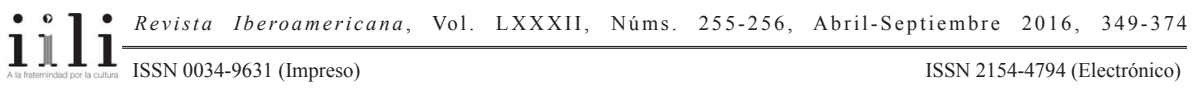


portugueses (Vieira, Cartas 81-91). ${ }^{33}$ En otro texto, Costa se referirá a este logro como la "malandragem [artimaña] diplomática do padre Antônio Vieira" ("De antropofagia" 9). En "A 'Decida'..." Costa llama la atención sobre el fracaso de dicho tratado de vasallaje y cita a Lisbôa, para quien esa paz resultó tan pomposa (apparatosa) como inane. Que la inscripción cultural o "paz" del americano con la "civilización europea" sea "nheengahiba" quiere decir que el conflicto colonial subsiste disimulado y que el triunfo civilizador no es ni completo ni definitivo. Costa celebra la continuidad de la barbarie bajo la impostura del tratado. La solución que sugiere es tautológica: para ser antropófago, "basta eliminar la impostura" (e implícitamente para develar la impostura basta ser antropófago). La paz nheengahiba de la modernidad colonial latinoamericana es engañosa o pérfida: oculta un conflicto; un resto diferencial; un entre-lugar tenso en el que - diría Silviano Santiago- la jerarquía entre original y copia está desestabilizada por la apropiación antropofágica.

\section{ESCRIBIR EN LA ARENA}

Uno de los párrafos más sugerentes de "A 'Descida'...” reitera el topoi de la fragilidad e impostura del proyecto colonial: "Foram estas as consequências dos versos ruimzizinhos que Anchieta escreveu na areia de Ithanhaen: Ordenações do Reino, gramática e ceia de Da Vinci na sala de jantar. E não houve ainda quem comesse Anchieta!” (8).

En la primera parte de este brevísimo párrafo, Costa hace referencia directa a la fugacidad de la escritura civilizatoria, al tiempo que alude elípticamente el tratado de paz con los tupinambás-tamoios, un siglo anterior al tratado de Vieira con los nheengahibas. En 1563 los jesuitas José de Anchieta (1534-1597) y Manoel da Nóbrega (1517-1570) se adentraron en territorio hostil indígena con la intención de pacificar a los caníbales tamoios que-confederados con varias tribus y aliados con los franceses-amenazaban la expulsión de los portugueses de la capitanía de São Vicente. Anchieta y Nóbrega fueron bien recibidos por los indios que, aunque interesados en un posible acuerdo, se mostraron listos a continuar la guerra. De junio 21 a septiembre 14 de 1563, Anchieta se quedó en Iperoig (Ubatuba) ${ }^{34}$ como rehén de los tupinambás-tamoios, bajo la amenaza de ser comido por los caníbales o seducido por sus mujeres (que es otra forma de ser comido). Entretanto, Nóbrega regresó a São Vicente en compañía del jefe Cunhambebe (hijo)

\footnotetext{
33 En una carta del 11 de febrero de 1660 escribía el jesuita "pacificador" al rey, refiriéndose al tratado: "por este meio accresceram a coroa e estados de vossa magestade, porque os que consideram a felicidade desta empreza, não só com os olhos no céu, senão tambem na terra, tem por certo que neste dia se acabou de conquistar o Estado do Maranhão, porque com os nheengaibas por inimigos seria o Pará de qualquer nação estrangeira que se confederasse com elles; e com os nheengaibas por vassallos e por amigos, fica o Pará seguro, e impenetravel a todo o poder estranho" (Cartas 90).

34 Ubatuba. En el litoral norte de São Paulo.
} 
para acordar los términos del que se conocerá como el Armisticio de Iperoig (Hemming 197-204). Es entonces, durante su cautiverio entre los tamoios, cuando Anchieta, en palabras de Costa, "escreveu na areia" los "versos ruimzizinhos" de su De Beata Virgine Dei Matre Maria. Según Juan Eusebio Nieremberg, Anchieta decidió “celebrar en verso latino toda la vida de la Madre de Dios" para "ocupar la imaginación" y apartarla tanto de la tentación de las "indígenas desnudas" como del temor de ser sacrificado por los caníbales (552). Como no tenía papel, escribió en la arena sus 5902 versos, que memorizó para salvarlos del efecto destructor de los elementos..$^{35}$ En la dedicatoria del poema, Anchieta revela las circunstancias diplomático-coloniales de su composición: "Aquí tienes, Madre Santísima, los versos que otrora te prometí, cuando rodeado de enemigos feroces, mi presencia domeñaba a los bravos tamoios y negociaba indefenso la paz". ${ }^{36}$

La obra poética y política de Anchieta inaugura la occidentalización del Brasil. Costa se burla de los "versos ruimzizinhos que Anchieta escreveu na areia" y tácitamente del Armisticio de Iperoig que esos versos aluden; tratado que posibilita la fundación de Rio de Janeiro (1565) y, en últimas, la colonización portuguesa. Costa explica que entonces no había “quem comesse Anchieta!" lo que por oposición significa que ahora sí hay quien lo haga (Antropofagia). Ruimzizinhos es un diminutivo enfático de ruim; quiere decir que los gloriosos versos a la virgen son malitos; o más exactamente, maluquitos; no alcanzan ni siquiera el estatuto de lo malo y, sin embargo, desencadenan una serie de fatídicas consecuencias que Costa enumera mediante referencias metonímicas al establecimiento del orden occidental -político-jurídico, cultural y religioso- en el Brasil; esto es, la imposición colonial de códigos legislativos portugueses (Ordenações do Reino), de disciplinas normativas metropolitanas sobre el lenguaje (gramática), y de un sistema de creencias y prácticas religiosas (el catolicismo ostensible en la copia de la Última cena de Leonardo da Vinci en el comedor familiar).

La reproducción local del mural L'Ultima Cena (1495-98) anuncia la preocupación del modernismo respecto de la cuestión de la inferioridad de la copia. ¿Qué significa que en un comedor brasileño se cuelgue una reproducción barata de otro comedor sagrado y clásico, contemporáneo del "descubrimiento" de América? Por un lado, es un signo de la conquista espiritual. Por el otro, la cena original universal es consumida en la cena vernácula, de manera que el signo del triunfo del cristianismo es al mismo tiempo el de su sometimiento al "selvagem comendo a cathechese." Costa asocia la antropo-teofagia católica a la alimentación y ambas cosas a las complejas vicisitudes

${ }^{35}$ Este episodio de la vida de Anchieta seguramente es una leyenda hagiográfica. El jesuita probablemente compuso el poema después de su liberación como pago de una promesa a la virgen (tal como la dedicatoria indica).

${ }^{36}$ Traducción prosificada de "En tibi quae vovi, Mater Sanctissima, quondam / Carmina, cum saevo cingerer hoste latus. / Dum mea Tamuyas praesentia mitigat hostes, / Tractoque tranquillum pacis inermis opus" (22).

$111 \frac{\text { Revista Iberoamericana, Vol. LXXXII, Núms. 255-256, Abril-Septiembre 2016, 349-374 }}{\text { ISSN 0034-9631 (Impreso) }}$ 
del consumo simbólico. La occidentalización es siempre paradójica. Recordemos que la Última cena representa tanto la institución de la eucaristía (que es la invitación a la repetición de una cena caníbal "original"), como el anuncio de la traición de Judas que es, por cierto, el tema central del mural de Da Vinci. La copia del original en el comedor brasileño sienta a manteles la perfidia cultural; convida al caníbal a la cena de la civilización.

\section{6. "Quatro séculos de carne de vacca! Que horror!"}

Costa termina su "A 'Descida' Antropophaga" con la frase surrealista "Quatro séculos de carne de vacca! Que horror!" La frase produce un efecto de ostranienie respecto del familiar consumo de carne bovina y, más importante aún, respecto de la modernidad colonial brasileña.

La introducción del ganado vacuno en el Brasil coincide con los comienzos de la colonización portuguesa. Desde mediados de la década de 1530 se importaron del archipiélago de Cabo Verde a São Vicente las primeras vacas para atender las necesidades de la naciente economía azucarera (Mariante y Cavalcante 50-52). La occidentalización del Brasil reduce y moderniza (o extermina) los caníbales al tiempo que aumenta el hato ganadero. Las vacas son signos del "progreso." Los caníbales devienen comedores de carne de res. El horror colonial, normalmente referido al caníbal devorador de carne humana, deviene horror frente a la modernidad colonial.

En el momento que Costa escribe, la ganadería es una de las fuerzas económicas que mueve el expansivo neocolonialismo brasileño. Según los datos del Instituto Brasileiro de Geografia e Estatística (IBGE), al empezar el siglo XX Brasil tiene casi 23 millones de cabezas de ganado y sólo 17 millones de habitantes. La modernización de las primeras décadas da lugar a un crecimiento de ambas cifras. Hacia 1920 hay poco más de 34 millones de vacas y la población alcanza 30 millones y medio. Brasil se convertirá en el primer exportador de carne del mundo.

La selección tropológica de Costa (la carne de vaca) apunta entonces tanto a la historia del colonialismo clásico como a la modernización periférica y neocolonial del Brasil. Los "cuatro siglos de carne de vaca" y de horror son cuatro siglos de "“descida' para a escravidão," de dominación, de colonialismo y de negación de la barbarie caníbal; cuatro siglos de not tupy.

Nótese que Costa parece reeditar aquí la melancolía moderna que hace del indígena una suerte de objeto simbólico de los que Freud llamó malestares en la cultura (Das Unbehagen in der Kultur). El horror frente a la carne de vaca sería un síntoma del malestar moderno frente a la modernidad. El caníbal nombraría las pérdidas; como en Montaigne. De esta manera, Costa parecería expresar el deseo por un regreso a un tiempo previo a la carne de vaca, la civilización y la ropa: "Portugal vestiu o selvagem.

$111 \frac{\text { Revista Iberoamericana, Vol. LXXXII, Núms. 255-256, Abril-Septiembre 2016, 349-374 }}{\text { ISSN 0034-9631 (Impreso) }}$ 
Cumpre despil-o para que ele tome um banho daquela 'inocencia contente' que perdeu e que o movimento antropophago agora lhe restitui" (“A 'Descida'...”). ${ }^{37}$ Empero, la utopía antropofágica no es retrógrada o melancólica. ${ }^{38}$ Costa -moderno y modernistaexpresamente rechaza el primitivismo o las añoranzas románticas:

Penso que não se deve confundir volta ao estado natural (o que se quer) com volta ao estado primitivo (o que não interessa). $\mathrm{O}$ que se quer é simplicidade e não um novo codigo de simplicidade. Naturalidade, não manuaes de bom tom. Contra a belleza canônica, a belleza natural -feia, bruta, agreste, bárbara, illógica. Instincto contra o verniz. O selvagem sem as missangas da cathechese. O selvagem comendo a cathechese. (“A 'Descida'...)

Costa perfila la Edad dorada de la utopía antropofágica en términos de simplicidad y descodificación valorativa de la cultura y el arte ("o que se quer"), lo cual se relaciona con su proyecto de descolonización del pensamiento ("pensamento novo brasileiro"). No le interesa la "vuelta" imposible a un estadio primitivo. Su utopía es pues todo futuro: corresponde a la imaginación de una modernidad-otra de la cultura brasileña que frente a la "civilización occidental" resiste comiendo.

\section{7. "BRASIL OCIDENTALIZADO"}

Oswaldo Costa representa un caso singular en el grupo de Antropofagia. Es él -no Andrade- quien reinstala el problema de la colonialidad de la modernidad occidental latinoamericana y reivindica los antagonismos de esa modernidad con temporalidadesotras o bárbaras que le son coetáneas; antagonismos falsamente apaciguados (mediante la "paz" nheengahiba). Por supuesto, estamos frente a declaraciones más o menos poéticas que relampaguean en medio de la polisemia y collage textual de un manifiesto modernista. En la Antropofagia de Costa hay más intuición interpretativa que teoría. ${ }^{39}$ Pero aún así, Costa es de todos los antropófagos el que con mayor énfasis ensaya una relectura contra-colonial de la Historia y la Cultura (con mayúsculas). En "Revisão necessária" - texto de la segunda dentição- hablará incluso de la necesidad de una

37 El poema "erro de português" de Oswald de Andrade sobre el mismo tema dice que los portugueses vistieron al indio porque llegaron un día de lluvia, y que si hubiera sido un día de sol hubiese sido al contrario (Poesias reunidas 177).

38 Llamo utopías retrogradas a aquellas cuyo telos está en el pasado (siempre imaginario aunque se lo conciba histórico); es decir, aquellas utopías que sitúan la Edad de oro en un tiempo ido que se añora recuperar y en las que la acción política corresponde a proyectos de restauración o recuperación de ese estadio perdido.

39 Recordemos que Costa abjura de "a razão pura" y del "preconceito racionalista" y afirma que Occidente "chegou aos limites da razão" ("De Antropofagia" 9).

$111 \frac{\text { Revista Iberoamericana, Vol. LXXXII, Núms. 255-256, Abril-Septiembre 2016, } 349-374}{\text { ISSN 0034-9631 (Impreso) }}$ 
corrección de la historiografía del Brasil, a la que reprocha que se base en hechos aislados y anécdotas y esté sometida a la mentalidad y los valores culturales y religiosos del vencedor, "a mentalidade reinol". Pide la apropiación y resignificación de la historia de los vencedores: una "crítica histórica" que trascienda el relato "do ponto de vista, falso, [...] do Ocidente." El "Brasil ocidentalizado" -arguye- "é, por tanto, um caso de pesudomorfose histórica (Consulte-se Spengler). Só a antropofagia consegue resolvêlo. Como: comendo-o" (1). Seguro del declive de Occidente, Costa cita la noción de pseudomorfosis histórica de su tocayo Spengler, quien a su vez la toma de la mineralogía, donde el término pseudomorfosis se refiere a la formación de ciertos cristales bajo la forma externa de otros. Un pseudomorfo es una forma falsa, una exterioridad aparente (Jackson et al. 523). Spengler habla de la pseudomorfosis histórica en su capítulo "Los problemas de la cultura arábiga" para referirse a transformación cultural y a la correspondiente subsistencia y resistencia, de una cultura bajo el dominio de otra:

By the term "historical pseudomorphosis" I propose to designate those cases in which an older alien Culture lies so massively over the land that a young Culture, born in this land, cannot get its breath and fails not only to achieve pure and specific expressionforms, but even to develop fully its own self-consciousness. All that wells up from the depths of the young soul is cast in the old moulds, young feelings stiffen in senile works, and instead of rearing itself up in its own creative power, it can only hate the distant power with a hate that grows to be monstrous. (Spengler 189)

Para Costa, la pseudomorfosis histórica tiene que ver con una de sus preocupaciones fundamentales: la eurocéntrica formación cultural brasileña bajo la forma asfixiante o caduca de Occidente; o, lo que es lo mismo, la deformidad de la cultura nacional cuando se la concibe como epifenómeno de Europa ("mentalidade reinol"). El canibalismo -arguye Costa- responde al dilema de la pseudomorfosis histórica "Comendo-o." En otras palabras, frente al "mal-estar" de la forma falsa y teratológica de lo "postiço" e "inauténtico," Costa no propone la subtração sino la deglutição que acabaría con el problema disolviendo la diferencia entre lo propio y lo ajeno. Antropofagia desafiaría entonces la idea de América y del Brasil como copias defectuosas de Europa, reformulando de manera afirmativa la imitatio como deglutição. Costa encuentra en el canibalismo -precisamente en este tropo inseparable de la otrificación de América y eje de la máquina discursiva del colonialismo- Otra modernidad: la caníbal. No creo que la Antropofagia de Costa haga una "interpretação triunfalista de nosso atraso" (como dice Schwarz del modernismo de Andrade de los años 20). En Costa encontramos más bien una interpretación de lo nacional contra el triunfalismo del imaginario occidental. El caníbal no es quien da la bienvenida a la modernidad eurocéntrica sino el personaje conceptual que enarbola desde la experiencia anómala de dicha modernidad, una utopía contra la misma.

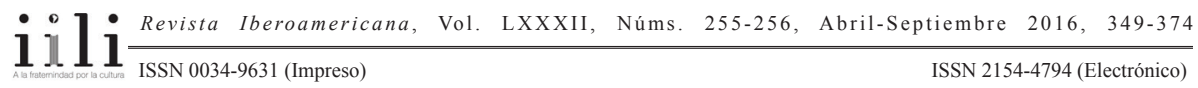


Es en Oswaldo Costa, entonces -y no tanto en Oswald de Andrade- que se avista un pensamiento utópico "descolonizador" o de "emancipação" cultural. Costa produce un descentramiento del horizonte identitario occidentalista del Brasil: no somos Europa sino una experiencia de Europa; y para Costa -recordémoslo- esa experiencia es colonial. Por esta razón, según él, pertenecemos a Occidente de manera conflictiva.

La Antropofagia de Costa es, como se anotó, fundamentalmente culturalista y letrada. Pero, aún así, contrasta - dado su insistente contra-colonialismo-con la frivolidad y vaciamiento político de varias de las articulaciones contemporáneas del tropo del canibalismo. Recordemos que no hace poco Antropofagia se convirtió en un eslogan corporativo que celebró la supuesta identidad caníbal del Brasil de la globalización, ${ }^{40}$ desconociendo el Brasil de los excluidos y los "Sem Terra", el Brasil de las favelas inverosímiles y en fin, el Brasil en que el colonialismo continúa. Si el pensamiento de Antropofagia se ha hecho leve, es entre otras razones, porque la canonización del movimiento ha ignorado casos como el de Oswaldo Costa, en cuyo pensamiento se asoma la imaginación política de una transmodernidad utópica.

Costa representa, aunque acallada, una voz alternativa no sólo frente las visiones canónicas de Antropofagia, sino al nacionalismo celebratorio de la pertenencia de Brasil a la globalización en la era neoliberal. Costa nombra el conflicto irresuelto que significa ser hijos de una modernidad colonial; pero también aventura un pensamiento descolonizador que se atreve a desafiar el monologo eurocéntrico y sus fórmulas coloniales de la modernidad, la civilización y el progreso.

* Agradezco a mis colegas Juliet Lynd, David Solodkow, Sarah Ann Wells, Graciela Esther Maglia Ferrari y Ben Heller, la lectura que hicieron de este ensayo y sus comentarios al mismo, y a Telê Ancona Lopez del Instituto de Estudos Brasileiros, su oportuna ayuda cuando comenzaba mi pesquisa sobre Costa. Parte de la investigación presentada aquí fue apoyada por la National Endowment for the Humanities, el "Internationales Gastdozentenprogramm des Freistaates Bayern" y el "Institut für Spanien-, Portugal- und Lateinamerikastudien" de la Universität Augsburg, y el Institute for Scholarship in the Liberal Arts (ISLA) de la University of Notre Dame.

${ }^{40}$ La XXIV Bienal de São Paulo (1998) conmemoró Antropofagia mediante una ostentosa exposición que escogió como su núcleo histórico el canibalismo y como su eje conceptual, la famosa "propuesta" antropofágica de Andrade, articulando así - gracias a una notable simplificación de esa metáfora cultural modernista- un ecléctico collage estético posmoderno que celebraba el "Brasil global" y el neoliberalismo (Jáuregui, Canibalia 548-551). 


\section{BiBLIOGRAFÍA}

Adour da Câmara, Jayme. “Enfarado do jornalismo" O Semanário 1/3 (Fev. 1957): 1, 3, 6. Amaral, Aracy A. Tarsila, sua obra e seu tempo. São Paulo: Editora 34: Editora da Universidade de São Paulo, 2003.

Anchieta, José de. José de Anchieta, primer mariólogo jesuita: texto latino de sus poemas mariológicos. Granada: Facultad de Teología, 1997.

Andrade, Carlos Drummond de. Tempo, vida, poesía. Rio de Janeiro: Record, 1986.

Andrade, Oswald de. "Manifesto da Poesía Pau Brasil". A utopia antropofágica. 1924.

São Paulo: Globo, 1990. 41-45.

"Manifesto Antropófago". Revista de Antropofagia. 1928. 1st dentição (1): 3 y

7. Facsimile. São Paulo: Abril, 1975.

Poesias reunidas. Rio de Janeiro: Civilização brasileira, 1978.

“A Arcádia e a inconfidência". A utopia antropofágica. 1945. São Paulo: Globo, 1990. 61-99.

"Um aspecto antropofágico da cultura brasileira: o homem cordial". A utopia antropofágica. 1950. São Paulo: Globo, 1990. 157-59.

"A crise da filosofia messiânica". A utopia antropofágica. 1950. São Paulo:

Globo, 1990. 101-55.

“A marcha das utopias". A utopia antropofágica. 1953. São Paulo: Globo, 1990. 161-209.

Os dentes do dragão (entrevistas). São Paulo: Globo, 1990.

Barbosa, Eloisa Goncalves y Lia Whyler. "The Brazilian Tradition in Translation Studies." The Encyclopedia of Translation Studies. Mona Baker, ed. Londres: Routledge, 1998. 326-32.

Bienal Internacional de São Paulo. XXIV Bienal de São Paulo: Núcleo histórico e historias de canibalismos. São Paulo: Fundação Bienal de São Paulo, 1998.

Boaventura, Maria Eugênia. A Vanguarda Antropofágica. São Paulo: Editora Ática, 1985. Comunicación personal electrónica. Abril 24, 2004.

Bopp, Raul. "Vida y muerte de Antropofagia". Revista de Cultura Brasileña 36 (1973): 20-40.

Cobra Norato e outros poemas. 6. ed. Rio de Janeiro: Livraria São José, 1956.

Brito, Leonardo Leonidas de. "A imprensa nacionalista no Brasil e o golpe. O Semanário". 22 mayo 2007. <http://www.observatoriodaimprensa.com.br/news/ view/a-imprensa-nacionalista-no-brasil-e-o-golpe-o-semanario>. 13 julio 2015.

Brito, Mario da Silva. As Metamorfoses de Oswald de Andrade. São Paulo: Conselho Estadual de Cultura, Comissão de Literatura, 1972.

Brydon Diana. Postcolonialism: Critical Concepts in Literary and Cultural Studies. Londres: Routledge, 2002.

$111 \frac{\text { Revista Iberoamericana, Vol. LXXXII, Núms. 255-256, Abril-Septiembre 2016, 349-374 }}{\text { ISSN 0034-9631 (Impreso) }}$ 
Campos, Augusto de. Introducción. "Revistas-Re-vistas: Os antropófagos". Revista de Antropofagia (facsímile), São Paulo: Abril, 1975. 1-13.

Balanço da bossa e outras bossas. São Paulo: Perspectiva, 1968.

Poesia, antipoesia, antropofagia. São Paulo: Cortez \& Morales, 1978.

Campos, Haroldo de. "Da razão antropofágica: A Europa sob o signo de devoração". Colóquio / Letras 62 (1981): 10-25.

"Tradición, traducción, transculturación: Historiografía y ex-centricidad". Filologia 22/2 (1987): 45-53.

Oswald de Andrade Trechos escolhidos. Rio de Janeiro: AGIR, 1967.

Cândido, Antônio. Varios escritos. São Paulo: Duas Cidades, 1970.

Cardoso Moraes, Tarcísio. "Geografia do poder: círculos intelectuais, natureza e historiografia na República paraense-século XX." Anais do XXVISimpósio Nacional de História-ANPUH, São Paulo, (julho 2011): 1-16. <www.snh2011.anpuh.org/ resources/anais/14/1300893365_ARQUIVO_GeografiadopoderANPUH2010. pdf>. 20 ene 2013.

Chamberlain, Bobby. "ParaAlém do Canibalismo: Teorias Contemporâneas da Literatura e da Cultura Brasileiras." Vertentes 13 (1999): 128-138.

Cocco, Giuseppe. "Anthropophagies, racisme et actions affirmatives." Brésil/Europe: repenser le Mouvement Anthropophagique. Papiers 60 (Sept. 2008): 57-74.

Coelho Netto, Jose Teixeira. Guerras culturais: Arte e política no novecentos tardio. São Paulo: Iluminuras, 2000.

Costa, Oswaldo. “A 'Descida'Antropophaga.” Revista de Antropofagia $(R A), 1^{\text {a }}$ dentição, num.1 (1928): 8.

"Revisão necessária." Revista de Antropofagia (RA) 2a dentição, num. 1,(1929): 1. “De Antropofagia." Revista de Antropofagia (RA) 2a dentição, num. 9 (1929): 1. “Moquém I:Aperitivo." Revista de Antropofagia (RA) 2a dentição, num. 4(1929): 1. "Moquem II: Hors de œuvre." Tamandaré. Revista de Antropofagia (RA) $2^{\mathrm{a}}$ dentição, num 5. (1929): 1.

d'Abbeville, Claude. Histoire de la mission des pères capucins en l'isle de Maragnan et terres circonvoisins. 1614. Graz, Austria: Akademische Druck-u, Verlagsanstalt, 1963.

Del Roio, Marcos. “Os comunistas, a luta social e o marxismo (1920-1940)”. História do Marxismo no Brasil - Partidos e organizações dos anos 1920 aos 196. Vol. 5. Marcelo Ridenti y Daniel Arão Reis, orgs. Campinas: editora da Unicamp, 11-72. Dussel, Enrique. Posmodernidady transmodernidad: diálogos con la filosofía de Gianni Vattimo. Puebla, México: Universidad Iberoamericana, 1999.

Fausto, Boris. História do Brasil. São Paulo: EDUSP, Fundação para o Desenvolvimento da Educação, 1994.

Ferraz-Gonçalves, Benedito Geraldo. Depois de tudo. São Paulo: Secretaria Municipal de Cultura, Prefeitura do Município de São Paulo: Paz e Terra, 1983.

$111 \frac{\text { Revista Iberoamericana, Vol. LXXXII, Núms. 255-256, Abril-Septiembre 2016, } 349-374}{\text { ISSN 0034-9631 (Impreso) }}$ 
Fernández Retamar, Roberto. "Calibán”. Casa de las Américas 68 (1971): 124-151. Concierto para la mano izquierda. La Habana: Casa de las Américas, 2000.

Figueiredo de Castro, Ricardo. "A Frente Única Antifascista (FUA) e o antifascismo no Brasil (1933-1934)." Topoi 5 (dezembro 2002): 354-88.

Fonseca, Maria Augusta. Oswald de Andrade, 1890-1954: Biografia. São Paulo: Secretaria de Estado da Cultura, Art Editora, 1990.

García Canclini, Néstor. Consumidores y ciudadanos: Conflictos multiculturales de la globalización. México, D.F.: Grijalbo, 1995.

Helena, Lúcia. Uma literatura antropofágica. Fortaleza: Universidade Federal do Ceará, 1983.

Hemming, John. Ouro vermelho: a conquista dos índios brasileiros. Carlos Eugenio Marcondes de Moura, trad. São Paulo: EDUSP, 2007.

IBGE. Instituto Brasileiro de Geografia e Estatística; Centro de Documentação e Disseminação de Informações (Brasil). Brasil, 500 anos de povoamento. Rio de Janiero: Instituto Brasileiro de Geografia e Estatística, 2000.

Estatísticas históricas do Brasil: séries econômicas, demográficas e sociais de 1550 a 1988. Rio de Janeiro: IBGE, 1990.

Jackson Julia A., James P. Mehl, Klaus K. E. Neuendorf. American Geological Institute. Glossary of Geology. Alexandria, VA: American Geological Institute, 2005.

Jáuregui, Carlos. Canibalia. Canibalismo, calibanismo, antropofagia culturaly consumo en América-Latina. 2005. Madrid: Vervuert, 2008.

"Antropofagia." Dictionary of Latin American Cultural Studies. Robert McKee Irwin and Mónica Szurmuk, eds. Gainesville: The UP of Florida, 2012. 22-28.

Leite, Serafim, ed. Cartas dos primeiros jesuitas do Brasil. 3 T. São Paulo: Comissão do IV centenário da cidade de São Paulo, 1954.

Lisbôa, João Francisco. Obras de João Francisco Lisbôa: natural do Maranhão 18121863. Vol. 2. Lisboa: Mattos Moreira \& Pinheiro, 1901.

Madureira, Luís. "A Flat Carnivalesque Intention of Being a Cannibal, Or, How (not) to Read the Cannibal Manifesto." ellipsis 9 (2011): 13-33.

Mariante, Arthur da Silva y Neusa Cavalcante. Animais do descobrimento: raças domésticas da história do Brasil = Animals of the Discovery: Domestic Breeds in the History of Brazil. Brasília, DF: Embrapa, 2000.

Nieremberg, Juan Eusebio. "P. José de Anchieta." Varones ilustres de la Compañía de Jesús. Vol. 3. Juan Eusebio Nieremberg y Alonso deAndrade. Bilbao:Administración de "El mensajero del Corazón de Jesús", 1889. 542-99.

Nunes, Benedito. “A antropofagia ao alcance de todos." A utopía antropofágica. Oswald de Andrade. São Paulo: Globo, 1990. 5-39.

“Antropofagismo e Surrealismo.” Remate de males 6 (1986): 15-25.

Nunes, Maria Luísa. "Becoming Whole: Literary Strategies of Decolonization in the Works of Jean Rhys, Frank Fanon and Oswald de Andrade." Proceedings of the

$111 \frac{\text { Revista Iberoamericana, Vol. LXXXII, Núms. 255-256, Abril-Septiembre 2016, 349-374 }}{\text { ISSN 0034-9631 (Impreso) }}$ 
Xth Congress of the International Comparative Literature Association. Vol. 3. Anna Balakian, ed. New York: Garland, 1985. 28-33

Perrone, Charles A. "Poesia concreta e tropicalismo." Revista USP 4 (1990): 55-64.

"Pau-Brasil, Antropofagia, Tropicalismo: The Modernist Legacy of Oswald de Andrade in Brazilian Poetry and Song of the 1960s-1980s." One Hundred Years of Invention: Oswald de Andrade and the Modern Tradition in Latin American Literature. K. David Jackson, ed. Austin: Abaporu Press, 1992. 133-54.

Prado-Bellei, Sergio Luiz. "Brazilian Antropophagy Revisited." Cannibalism and the Colonial World. Francis Barker et al, ed. Cambridge: Cambridge UP, 1998. 87-109. Revista de Antropofagia [RA] (facsímile). Augusto de Campos (introd.). São Paulo: Abril, 1975.

RodríguezNúñez, Víctor. “Calibán, ¿antropófago? La identidad cultural latinoamericana de Oswald de Andrade a Roberto Fernández Retamar”. Obras incompletas. Oswald de Andrade. Jorge Schwartz, ed. Paris: Archivos, 2003. 1095-1109.

Rufinelli, Jorge y João Cezar de Castro Rocha, eds. Anthropophagy Today. Nuevo texto crítico. Stanford, CA, 2000.

Sá, Lúcia. Rain Forest Literatures Amazonia Texts and Latin American Culture. Minneapolis: U of Minnesota P, 2004.

Santa Rosa, Henrique A. Historia do rio Amazonas: 11.a these da 2.a sub-secção do Congreso internacional de historia da America. Pará: Officinas Graphicas do Instituto Lauro Sodré, 1926.

Santiago, Silviano Uma literatura nos trópicos ensaios sobre dependência cultural. São Paulo: Editora Perspectiva, 1978.

Schwarz Roberto, Misplaced Ideas: Essays on Brazilian Culture. Londres: Verso, 1992.

"Nacional por subtração." Que Horas São? São Paulo: Companhia das Letras, 2006. 29-48.

Shklovsky, Victor. “Art as technique." Modern Criticism and Theory: A Reader. David Lodge, ed. Londres: Longman, 1988. 15-30.

Soares dos Santos, Leonardo. “Do que 'os Livros Diziam’ à Rua da Glória, n. 52: o PCB e a ‘questão camponesa'(1927-1947)”. Revista IDeAS3/2 (jul./dez. 2009): 389-424.

Sodré, Nelson Werneck. História da literatura brasileira. São Paulo: Disfel, 1982. História da imprensa no Brasil. Rio de Janeiro: Civilização Brasileira,1966.

Spengler, Oswald. The Decline of the West. Perspectives of World History. Vol. 2. Charles Francis Atkinson, trad. Londres: Allen and Unwin, 1928.

Stam, Robert. Subversive Pleasures: Bakhtin, Cultural Criticism, and Film. Baltimore, MD: Johns Hopkins UP, 1992.

Unruh, Vicky. Latin American Vanguards: The Art of Contentious Encounters. Berkeley: U of California P, 1994.

Vieira, António. Cartas do padre Antonio Vieira. Vol. 1. Lisboa: J.M.C. Seabra \& T.Q. Antunes, 1854-1855. 
Vieira, Else Ribeiro Pires. "Liberating Calibans: Readings of Antropofagia and Haroldo de Campos' Poetics of Transcreation." Post-Colonial Translation: Theory and Practice. Susan Bassnett y Harish Trived, eds. Londres: Routledge, 1999. 95-113.

Viveiros de Castro, Eduardo. "Entrevista." Saque/Dádiva. Revista Azougue: edição especial 2006-2008. Sergio Cohn, Pedro Cesarino e Renato Rezende, orgs. Rio de Janeiro: Beco do Azougue, 2008. 23-36.

Wylie, Lesley. Colonial Tropes and Postcolonial Tricks: Rewriting the Tropics in the "Novela de la selva". Liverpool: Liverpool University, 2009. 